\title{
Effect of different preceding crops and land preparation methods on the agrophysiological and health parameters of Hevea brasiliensis Muell. Arg clone GT 1 in southwestern Côte d'Ivoire
}

\section{Ballo Esperence Kouadio \\ Soumahin Eric Francis}

Université Jean Lorougnon Guede, UFR Agroforesterie, Laboratoire d'amélioration des productions agricoles, Daloa, Côte d'Ivoire

\section{Ballo Koffi Celestin}

Centre National de Recherche Agronomique (CNRA), Direction Générale, Abidjan, Côte d'Ivoire

\section{Elabo Agnyman Eliathe Angeline}

Centre National de Recherche Agronomique (CNRA),

Station de Recherche de Bimbresso, Abidjan, Côte d'Ivoire

\section{Adou Bini Yao Christophe}

Université Nangui Abrogoua, UFR Sciences de la Nature, Laboratoire de Biologie et Amélioration des Productions Végétales, Abidjan, Côte d'Ivoire

\section{Kouadio Yatty Justin}

Université Jean Lorougnon Guede, UFR Agroforesterie, Laboratoire d'amélioration des productions agricoles, Daloa, Côte d'Ivoire

\section{Obouayeba Samuel}

Centre National de Recherche Agronomique (CNRA),

Station de Recherche de Bimbresso, Abidjan, Côte d'Ivoire

Doi: 10.19044/esj.2018.v14n33p369 URL:http://dx.doi.org/10.19044/esj.2018.v14n33p369

\begin{abstract}
Land preparation method and preceding crops affect the evolution of rubber trees. Its ignorance and/or poor execution do not allow the efficient development of the agronomic and economic potentialities of plantations. In order to remove this constraint, a study was undertaken in southwestern Côte d'Ivoire. The rubber trees were planted at 510 trees/ha according to a Fisherblock experimental design, of six preceding crop treatments with three repetitions. Only one latex harvesting system was applied (S/2 d/4 6d/7 ET $2.5 \% \mathrm{~Pa} 1$ (1) 6/y). The parameters measured were rubber yield, annual average girth increment, physiological profile, sensitivity to tapping panel dryness and sensitivity to root rot caused by the genus Fomes. The results
\end{abstract}


showed that the rate of rubber trees found in the plots was good $(90.73 \pm 0.47$ $\%$ ) and had varied with land preparation method depending on the preceding crops. Vegetative growth at tapping $\left(2.05 \pm 1.36 \mathrm{~cm} . y^{-1} \mathrm{rr}^{-1}\right)$, and average rubber yield $\left(2053 \pm 179 \mathrm{~kg} \cdot \mathrm{ha}^{-1} \cdot\right.$ year $\left.^{-1}\right)$ and the rate of tree loss due to the genus Fomes $(8.33 \pm 0.42 \%)$ were influenced by land preparation method. The good productivity, the good physiological state of the rubber trees were characterized by a well balanced physiological profile and a tapping panel dryness rate $(3.60 \pm 1.74 \%)$, independently of treatments. The Agroeconomic results showed that mechanically prepared fallow (813641 FCFA.ha ${ }^{-1}$.year $^{-1}$ ) was the best preceding crop and land preparation method. This technical result has two main interests for the national rubber-growing industry, since it actively participates in the national policy for fighting against deforestation but also contributes to the establishment of a secondary forest by the attributes of the rubber-growing plant cover.

Keywords: Côte d'Ivoire; Hevea brasiliensis; Preceding crop; land preparation method; Profit margin; Root rot caused by Fomes

\section{Introduction}

Nowadays, with the climate change context (Brou et al., 2005; Kouassi et al., 2008), it is important to use good cropping practices, for a better development (good vegetative growth and a good yield) of the agronomic potentialities of the different clones of Hevea brasiliensis planted (Pathiratna et al., 2006). In order to sustainably maintain and even improve rubber tree productivity, many works have been done in the field of plant physiology (Jacob et al., 1988; 1995; 1998; Obouayeba et al., 2000). Thus, various methods contribute to such sustainability, especially, the use of cropping techniques. Works of great interest, have been led in this regard (Obouayeba et al., 2005; Pathiratna et al., 2006). The different techniques consist in applying cropping strategies so as to adapt them to the biological capacities of the rubber tree (Pathiratna and Perera, 2003). Indeed, in the rubber-growing industry, the conditions for setting up a plantation are factors determining the success of the latter (Seneviratne and Privani, 2005). Therefore, the preceding crop of a rubber tree plantation is of particular importance (Le roux, 1994). On the one hand, it dictates the technique of plot preparation (felling, clearing, mere weeding...) sensibly influencing the extent of the investment required for its implementation. On the other hand, its nature sensibly impact the phytosanitary condition of trees, particularly on the risk of root disease due to the presence of soil fungi, including the genus Fomes (Delabarre and Eschbach, 2002). However, the effect of preceding crop and land preparation interaction on the evolution of rubber trees is unknown to some farmers and in practice land preparation is not executed with mastery by others or is 
expensive in their achievement. All this leads the non-industrial sector farmer(s) to practices that do not allow the efficient development of the agronomic and economic potential of these plantations. Faced with this reality, it was found necessary to better direct non-industrial sector rubber tree growers from an agronomic and economic point of view towards the selection of cropping techniques adapted to Hevea brasiliensis clone GT 1, which is the most planted in Côte d'Ivoire.

It is in this context that this study, which aims at comparing, on the basis of agronomic and economic criteria, different land preparation techniques depending on the preceding crop and studying their influence on the evolution of Hevea brasiliensis clone GT 1 on the experimental site of the GO (Former HEVEGO), today, Société Civile Agricole du Sud-Ouest (Agricultural Civil Society of the South-West)(SCASO) in southwestern Côte d'Ivoire, in order to select the best one(s).

\section{Materials and Methods}

\section{Plant Material}

The plant material used consisted of Hevea brasiliensis (Mueller Argoviensis Euphorbiaceae)clone GT 1, belonging to vegetative growth classes (Obouayeba et al., 2000; Obouayeba, 2005) and of moderate metabolic activity (Jacob et al., 1988). Its selection was motivated by its hardiness, which makes it the most grown clone in the country, giving it a good and stable population of tapped trees (Chapuset et al., 2000).

\section{Methods \\ Study Site}

The works were carried out at the research station of the Gô (Former HEVEGO), today, Société Civile Agricole du Sud-Ouest (Agricultural Civil Society of the South-West) (SCASO) in southwestern Côte d'Ivoire (West Africa). This area is subject to a humid equatorial climate, characterized by heavy rainfall. The annual average temperature was $26.1^{\circ} \mathrm{C}$. The annual average rainfall was $1900 \mathrm{~mm}$. The heaviest rains fall from April to July (Figure 1). A relatively dry season starts in December and extends to March (Monnier, 1983; Keli et al., 1992; Brou et al., 2005).The predominantly ferralitic soils are, however, derived from migmatites and shale, sandy clayed, relatively richer in exchangeable bases. They also have gravel horizons and frequent lateritic cuirasses around $1.00 \mathrm{~m}$ deep (Keli et al., 1992). 


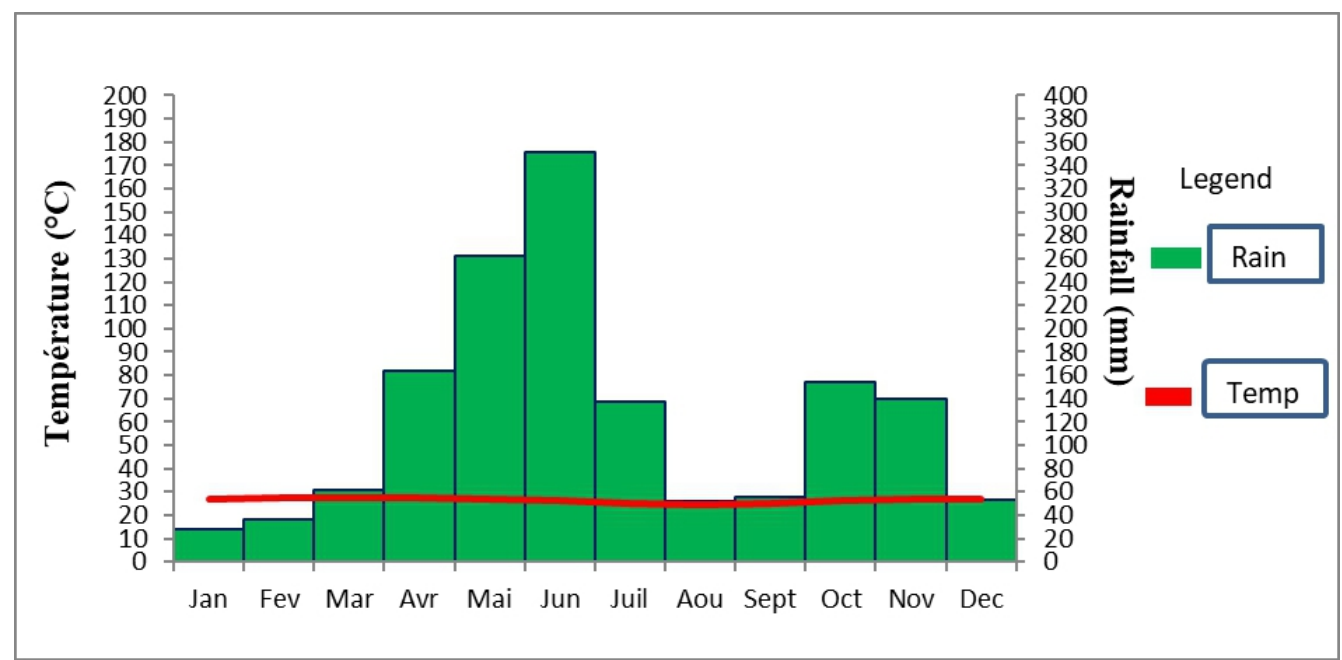

Figure 1: Ombrothermal diagram of the area of study over the period 1990-2006

(Source: SODEXAM San Pedro Airport).

\section{Experimental Protocol}

The experiment was set up in June 1990 and the rubber trees started being tapped in September 1996. The experiment was conducted in downward tapping for nine years with clone GT 1, on the experimental site of the GO (Former HEVEGO), today, Société Civile Agricole du SudOuest(Agricultural Civil Society of the South-West)(SCASO) in southwestern Côte d'Ivoire. The experimental design was Fischer blocks of six treatments with three repetitions, on a surface area of about $22.57 \mathrm{ha}$, planted at a density of 510 trees/ha (7 meters apart for rows and 2.8 meters apart for plants). It should be noted that a portion of the manually prepared fallow plot was stripped prior to trial installation. Clone GT 1 was subjected to different treatments as shown in Table 1.

Table 1: List of different treatments applied to clone GT 1 for nine years of experimentation

\begin{tabular}{l|l}
\hline \multicolumn{1}{c|}{ Treatments } & \multicolumn{1}{c}{ Description } \\
\hline Fallow ma (control) & Manually cut down fallow, followed by site manual digging \\
\hline Forest dév. & $\begin{array}{l}\text { Manually cut down forest, followed by plant debris slash-and-burn } \\
\text { and site manual digging }\end{array}$ \\
\hline Forest l.v. & $\begin{array}{l}\text { Mechanically cut down forest, followed by row opening with a V- } \\
\text { shaped shovel }\end{array}$ \\
\hline Forest man. & Manually cut down forest, followed by site manual digging \\
\hline Fallow l.v. & $\begin{array}{l}\text { Mechanically cut down fallow, followed by row opening with a V- } \\
\text { shaped shovel }\end{array}$ \\
\hline Forest and. & $\begin{array}{l}\text { Mechanically cut down forest, followed by plant debris clearing from } \\
\text { the entire plot by grouping them into a central swath }\end{array}$ \\
\hline
\end{tabular}




\section{Latex Harvesting Technology \\ Tapping System}

All treatments started to be tapped at the same time, that is, at 6 years 3 months after planting. Only one latex harvesting system was applied to all treatments; half-spiral downward tapping every four days, with a day off (Sunday) in the week, with application of $1 \mathrm{~g}$ of $2.5 \%$ Ethephon-concentrated stimulant paste over $1 \mathrm{~cm}$ wide on the tapping panel; six applications per year (S/2 d/4 6d/7 and 2.5\% Pa 1 (1) 6/y). The tapping took place the first two years on panel A (BO-1) and the third year on panel B (BO-2), with subsequent alternating annual tapping, from the $4^{\text {th }}$ year, of both panels up to the ninth year of tapping (Gohet et al., 1991).

\section{Measurements Made}

\section{Rubber Yield}

The harvest was recorded tree by tree, with one check every four weeks, that is, every six tappings. It was collected on-farm in a coagulated state. This coagulation was done naturally in polyethylene bags or "polybags".

The cumulative yield of six tappings representing the mass of fresh material produced per treatment, was weighed using a scale before and after creping so as to determine the conversion factor (CT). This conversion factor (CT), which is the dry matter percentage of a given sample of fresh rubber, was used to calculate dry rubber yield in gram per tree per tapping $\left(\mathrm{g} \cdot \mathrm{t}^{-1} \cdot \mathrm{t}^{-1}\right)$; in gram per tree per year $\left(\mathrm{g}^{-1} \mathrm{t}^{-1}\right.$.year $\left.{ }^{-1}\right)$ and in kilogram per hectare per year $\left(\mathrm{kg} \cdot \mathrm{ha}^{-1} \cdot\right.$ year $\left.^{-1}\right)$.

\section{Rubber Tree Trunk Thickness Growth}

Rubber tree trunk thickness growth was assessed from girth measurements at $1.70 \mathrm{~m}$ above ground, using tape measures. Measurements were made at trial set up and then once a year, during the last quarter of the period of normal metabolic activity of rubber trees (October, November or December). Indeed, this period being just before the start of natural defoliation (January to February), coincides with a very weak vegetative growth of rubber trees. The annual average girth increment after nine years of experiment was expressed in centimeters per year $\left(\mathrm{cm}\right.$. year $\left.^{-1}\right)$.

\section{Tapping Panel Dryness Survey}

It was carried out at the beginning and the end of the experiment then, once per year in November. The survey was performed by visually estimation of the unproductive tapping panel length under the effect of treatments, in order to determine the percentages of diseased panel length (LEM). Indeed, the observer followed the tapper and assigned a mark between " 0 " and " 6 " to 
each tapped rubber tree depending on the significance of the unproductive tapping panel length. These marks are defined as follows:

" 0 " indicated a normal flow of latex over the entire length of the tapping panel which was said to be safe.

" 1 "meant that 1 to $20 \%$ of the tapping panel length was dry;

" 2 " meant that 21 to $40 \%$ of the tapping panel length was dry;

" 3 " meant that 41 to $60 \%$ of the tapping panel length was dry;

" 4 " meant that 61 to $80 \%$ of the tapping panel length was dry;

" 5 " meant that 81 to $100 \%$ of the tapping panel length was dry;

" 6 " meant that the tree was tapped, but did not yield latex and the tapping would therefore be stopped.

Fallen, broken trees or the ones affected by foliar diseased were not taken into account. The percentage of diseased panel length (LEM) for each treatment was determined from the following formula: $\mathbf{L E M}(\%)=(0.1 \mathrm{n} 1+0.3 \mathrm{n} 2+$ $0.5 \mathrm{n3}+0.7 \mathrm{n4}+0.9 \mathrm{n5}+\mathrm{n6}+\mathrm{ES}) \mathrm{x} \mathrm{N}^{-1}$

$\mathrm{N}$ : total number of rubber trees tested; ni: number of trees per class of tapping panel dryness; ES: number of trees whose tapping has been stopped for total tapping panel dryness.

\section{Determination of Rubber Trees Infected by Root Rot caused by the Genus Fomes}

A survey of trees infected by root rot caused by the genus Fomes was conducted at the beginning and end of the experiment and then once per year in November. The survey was carried out by visual estimation and counting of diseased rubber trees as a result of the treatments, in order to monitor the onset and the progress of root rot caused by the genus Fomes (Wahounou et al., 2017).

For each treatment, the percentage of living trees (Living Trees \%) was determined by the following relationships:

$\mathbf{N A V}=\mathbf{N}-\mathbf{N A S}$

NAV:number of living trees;

Ntotal number of trees;

NAS:number of dry trees.

\section{$\% \mathrm{NAV}=\mathrm{NAV} \times 100 \times \mathrm{N}^{-1}$}

\section{Determination of the Physiological Parameters of the Latex}

The most important physiological parameters of the latex, due to their involvement in mechanisms related to rubber yield, were analyzed once per year, in November. These included dry rubber and sucrose, inorganic phosphorus and thiol group contents of the latex. The latex taken by stinging 
under the tapping panel (downward tapping), according to the "latex microdiagnosis" (MDL) method, made it possible to determine the quantities of physiological parameters (Jacob et al., 1988, Prévôt et al. 1986). The dry rubber content was determined from a 1-ml latex sample of each treatment rubber trees. This latex was weighed in glass pill boxes before and after being placed in an oven at $80^{\circ} \mathrm{C}$ for 24 hours. The dry rubber content (Ex.S) expressed as a percentage was defined by the following formula: Ex.S $(\%)=$ (Dry latex mass / Fresh latex mass) x 100.

Moreover, a $1 \mathrm{ml}$ latex sample was mixed with $9 \mathrm{ml}$ of $2.5 \%$ trichloroacetic acid (TCA) in glass pill boxes. trichloroacetic acid caused latex coagulation, whose serum content was "expressed" by means of metal forceps. The coagulated latex (rubber) was separated from the TCA and the resulting solution was filtered through cotton to remove impurities, including rubber particles remaining in suspension. The filtrate obtained called "trichloroacetic serum" was used for determining sucrose, inorganic phosphorus and thiol groups of the latex.

\section{Determination of the Sucrose of the Latex}

The sucrose of the latex was determined by the Anthrone method developed by Ashwell in 1957. In the presence of concentrated sulfuric acid hexoses dehydrated into furfural which reacted with Anthrone giving a bluegreen color whose absorbance was measured spectrophotometrically at wavelength $\lambda=627 \mathrm{~nm}$. Using glass test tubes, a volume of $50 \mu \mathrm{l}$ of the TCA serum of the treatments was added respectively to $450 \mu \mathrm{l}$ of $2.5 \%$ TCA against $0.5 \mathrm{ml}$ of $2.5 \%$ TCA for the control. Three (3) $\mathrm{ml}$ of Anthrone reagent were introduced into all the tubes. The solutions were homogenized and then heated in a water bath for $5 \mathrm{~min}$ at a temperature of $37^{\circ} \mathrm{C}$. After cooling, the optical densities (OD) were read spectrophotometrically at wavelength $\lambda=627 \mathrm{~nm}$. Fructose, which is one of the constituents of sucrose (sucrose $=$ glucose + fructose), dehydrated easily. As for the second constituent, glucose, its reaction required heating. Fructose (without heating) or all of the hexoses (fructose and glucose) could therefore be determined separately if the solutions were heated. The sucrose content of the latex was then determined and then expressed in millimoles per liter of latex $\left(\mathrm{mmol} . \mathrm{l}^{-1}\right)$ from the determination of solutions of the calibration range.

\section{Determination of the Inorganic Phosphorus of the Latex}

The inorganic phosphorus of the latex was determined by the ammonium molybdate method developed by Taussky and Shorr in 1953. Phosphorus formed a complex with molybdate and vanadate giving a yellow color, whose absorbance was measured by the spectrophotometer at wavelength $\lambda=410 \mathrm{~nm}$. In glass test tubes, a volume of $0.5 \mathrm{ml}$ of TCA serum 
from the treatments against $0.5 \mathrm{ml}$ of distilled water for the control, was added to $1 \mathrm{ml}$ of $2.5 \%$ TCA. Three (3) $\mathrm{ml}$ of phosphorus reagent were then introduced into all the tubes. The solutions were homogenized and then the optical densities (OD) read in the spectrophotometer at wavelength $\lambda=410$ $\mathrm{nm}$. The Pi content of the latex was then determined and susequently expressed in millimoles per liter of latex $\left(\mathrm{mmol}^{-1} \mathrm{l}^{-1}\right)$ from the determination of solutions of the calibration range.

\section{Determination Thiol Groups of the Latex}

The thiol groups of the latex were determined by the Boyne and Ellman (1972) method using dinitro-2.2-dithio-5.5'-dibenzoic acid (DTNB). Indeed, the thiol groups (R-SH) reacted with the DTNB to give the nitro-2-thio-5benzoic acid (TNB) whose absorbance was measured spectrophotometrically at wavelength $\lambda=410 \mathrm{~nm}$ (Ellman's reaction). In glass test tubes, a volume of $1.5 \mathrm{ml}$ of TCA serum from the treatments against $1.5 \mathrm{ml}$ of $2.5 \%$ TCA for the control, was added to $1 \mathrm{ml}$ of $2.5 \%$ TCA. Fifty (50) $\mu \mathrm{l}$ of DTNB were then introduced into all the tubes. The solutions were homogenized and then the optical densities (OD) read in the spectrophotometer at wavelength $\lambda=410$ $\mathrm{nm}$. The content of thiol groups of the latex was then determined and susequently expressed in millimoles per liter of latex $\left(\mathrm{mmol} . \mathrm{l}^{-1}\right)$ from the determination of solutions of the calibration range.

\section{Study of the Economic Profitability of Different Plot Preparation Methods Depending on the Preceding Crop Data Collection}

The data collection was carried out according to the experimental design relating to the different methods of plot preparation depending on the preceding crop. Rubber yield data were collected in experimental plots of SCASO. For this experiment, Rubber yield and operating costs (land preparation cost) data collected were subjected to an economic analysis.

\section{Economic Calculations}

The economic profitability of the different plot preparation techniques depending on the preceding crop was analyzed. The index considered was the profit margin (MB). Margins were calculated and compared depending on the preceding crop (forest or fallow) and plot preparation techniques. The MB was obtained by the difference between Recipe (R) and Production Cost (CP) according to Equation 1. (CFAF.ha' ${ }^{-1}$ year $^{-1}$ )

$M B\left(C F A F . h a^{-1}\right.$.year $\left.{ }^{-1}\right)=R(C F A F /$ ha/year $)-C P\left(C F A F . h a^{-1}\right.$.year $\left.{ }^{-1}\right) \ldots \ldots .(1)$ 
The recipe was the product of the amount $(\mathrm{Q})$ of fresh rubber harvested multiplied by the farm gate sales price (PA) of fresh rubber following Equation 2.

$R\left(C F A F \cdot h a^{-1} \cdot\right.$ year $\left.^{-1}\right)=Q\left(K_{g} \cdot h a^{-1} \cdot\right.$ year $\left.^{-1}\right) \times P A\left(F C F A \cdot K^{-1}\right)$

The amount of rubber was the annual average value over the nine (9)year period (1996 to 2005) yielded by clone GT 1 studied. The average selling price considered was $322 \mathrm{CFAF} . \mathrm{Kg}^{-1}$ corresponding to the discounted average value of the price of fresh rubber in the post-devaluation period from 1994 to 2011 (Mahyao et al., 2014).

The Production Cost (CP) was mainly composed of the cost of land preparation ( $\mathrm{K}$ under the hypothesis that all other variables were otherwise equal (ceteris paribus) between years two and six. The CP was calculated according to Equation 3.

$\mathrm{CP}\left(\mathrm{CFAF} \cdot \mathrm{ha}^{-1} \cdot \mathrm{year}^{-1}\right)=\mathrm{K}$

With: K (CFAF.ha ${ }^{-1}$ year $\left.^{-1}\right)=$ Land Preparation Cost

\section{Statistically Analyses}

Data relating to rubber yield, trunk isodiametric growth, latex microdiagnosis, diseased panel length and trees affected by the genus Fomes were processed using STATISTICA 7.5software. An analysis of variance was performed and the significance level of the differences between averages was estimated by the NEWMAN-KEULS test at 5\% threshold.

\section{Results}

Effects of different land preparation methods depending on the preceding crop on clone GT 1 after nine years of experiment

\section{Living Tree Rate}

The average rate of living trees $(\%)$ six years after land preparation was good $(94.57 \pm 0.51 \%)$. Similarly, the average rate of living trees, 15 years after land preparation depending on the preceding crop, remained good (90.73 $\pm 0.47 \%)$.

The different preceding crops and land preparation methods had a significant impact on the average rate of clone GT 1 living trees in plots at tree tapping start and at the end of experiment (Table 2).

At tapping start, the average rate of trees found on the plots was significantly influenced by the preceding crop and land preparation method. Indeed, the rate of living trees of the different Fallow l.v (97.02 $\pm 0.20 \%)$ and Forest 1.v $(97.7 \pm 0.75 \%)$ treatments were statistically higher than those of the other treatments, especially, the control plot. Finally, "Forest Dev and Fallow ma" treatments showed statistically identical living tree rates ranging from 
$87.9 \pm 0.82 \%$ to $93.8 \pm 0.44 \%$.At the end of experiment, the Fallow 1.v (96.4 $\pm 0.72 \%$ ) plot recorded the rate of living trees which was significantly higher than those of the other treatments which were also statistically different. The rate of loss of experimental trees on the plots was low overall $(9.27 \%$, Table 2).

Table 2: Population of clone GT 1 subjected to different preceding crops and land preparation methods after nine years of experiment

\begin{tabular}{c|cc}
\hline Treatments & \multicolumn{2}{c}{ Living Trees\% } \\
\hline & Beginning (At tapping start) & End (After 15 years of experiment) \\
\cline { 2 - 3 } Fallow ma. $(\mathbf{C o})$ & $\mathbf{9 3 . 8} \pm \mathbf{0 . 4 4} \mathbf{c}$ & $\mathbf{9 1 . 8} \pm \mathbf{0 . 3 6} \mathbf{~ b}$ \\
Forest dév. & $87.9 \pm 0.82 \mathrm{c}$ & $81.3 \pm 0.27 \mathrm{c}$ \\
Forest l.v. & $97.7 \pm 0.75 \mathrm{a}$ & $89.9 \pm 0.45 \mathrm{c}$ \\
Forest man. & $95.01 \pm 0.27 \mathrm{~b}$ & $92.8 \pm 0.44 \mathrm{~b}$ \\
Fallow l.v. & $97.02 \pm 0.20 \mathrm{a}$ & $96.4 \pm 0.72 \mathrm{a}$ \\
Forest and. & $96.01 \pm 0.60 \mathrm{~b}$ & $92.2 \pm 0.56 \mathrm{~b}$ \\
\hline Average & $\mathbf{9 4 . 5 7} \pm \mathbf{0 . 5 1}$ & $\mathbf{9 0 . 7 3} \pm \mathbf{0 . 4 7}$ \\
\hline
\end{tabular}

In the same column, the averages followed by the same letter are not significantly different

(Newmann-Keuls test at $5 \%$ ). Liv Tre: Living trees expressed in percentage; Co: control

\section{Rubber Yield}

\section{Per Tree and per Tapping $\left({\left.\mathrm{g} . \mathrm{t}^{-1} \cdot \mathrm{t}^{-1}\right)}^{-1}\right.$}

After nine years of experiment, the annual average yield per tree and per tapping of GT $1(57.67 \pm 5.6 \mathrm{~g}$, Table 3$)$ was satisfactory overall, all preparation methods depending on the preceding crop combined. The land preparation method depending on the preceding crop significantly influenced the annual average yield per tree and per tapping. Indeed, the control treatment (Fallow ma, $46 \pm 4.3 \mathrm{~g} . \mathrm{a}^{-1} \cdot \mathrm{s}^{-1}$ ) recorded a yield that was less significant than that of all other treatments (Fallow l.v; Forest l.v; Forest man; Forest and; Forest dev) whose yields were statistically identical $\left(58 \pm 4.7\right.$ to $63 \pm 8.1 \mathrm{~g} . \mathrm{a}^{-}$ ${ }^{1} \cdot \mathrm{s}^{-1}$, Table 3).

\section{Per Tree and per Year $\left(\right.$ g.t $^{-1}$.year- $\left.{ }^{1}\right)$}

In nine years of trial, the annual average yield of a rubber tree expressed in grams per tree per year $\left(4405 \pm 370\right.$ g.t $\mathrm{t}^{-1}$.year $\left.{ }^{-1}\right)$ of clone GT 1was good (Table 3). The rubber yield of the treatments ranged between 3556 and 4812 g.t $\mathrm{t}^{-1}$.year ${ }^{-1}$. The lowest rubber yield $\left(3556 \pm 315\right.$ g.t $\mathrm{t}^{-1}$.year $\left.{ }^{-1}\right)$, was obtained with the control treatment (Fallow ma). The rubber yield of the plot (Forest 1.v, $4812 \pm 350 \mathrm{~g} \cdot \mathrm{a}^{-1} \cdot \mathrm{year}^{-1}$ ) was statistically higher than that of the control (fallow ma; $3556 \pm 315$ g.t $\mathrm{t}^{-1}$.year ${ }^{-1}$ ) and equivalent to all other land preparation methods depending on the preceding crop (Table 3 ). 


\section{Productivity per Hectare}

Table 3 shows the annual average yield in kilograms per hectare per year $\left(2053 \pm 179 \mathrm{~kg} \cdot \mathrm{ha}^{-1} \cdot \mathrm{year}^{-1}\right)$. Overall, the most yielding treatment was preceding crop Fallow, whose beneficial effect has been accentuated by mechanized labor (2280 kg.ha ${ }^{-1} \cdot$ year $^{-1}$, Table 3). All treatments that had forest or fallow as preceding crop regardless of the land preparation technique, were more yielding than the control treatment (Fallow ma, $1574 \mathrm{~kg} \cdot \mathrm{ha}^{-1} \cdot \mathrm{year}^{-1}$ ). These plots (Fallow 1.v, Forest 1.v, Forest man, Forest and; Forest dev) had statistically identical yields ranging between 2022 and $2280 \mathrm{~kg} \cdot \mathrm{ha}^{-1}$.year $^{-1}$.

\section{Trunk Thickness Vegetative Growth}

Clone GT 1 showed a satisfactory annual average girth increment (2.05 $\pm 1.36 \mathrm{~cm}$ year $^{-1}$ ), independently of all the treatments of the experiment (Table 3). All plots in the trial had annual average rubber tree girth increment significantly higher than that of the control treatment (fallow ma, 1.51 $\mathrm{cm}$ year $\left.{ }^{-1}\right)$. Indeed, they were significantly identical to each other and oscillated between (2.02 and $\left.2.36 \mathrm{~cm}_{\text {.year }}{ }^{-1}\right)$. The lowest increase was observed with the control plot, which had the lowest recorded yield.

Table 3: Average rubber yield of clone GT 1 subjected to different preceding crops and land preparation methods after nine years of experiment

\begin{tabular}{|c|c|c|c|c|}
\hline Treatments & Yield $\left(g . t^{-1} \cdot t^{-1}\right)$ & 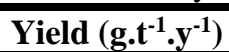 & Yield $\left(\mathrm{kg} \cdot \mathrm{ha}^{-1} \cdot \mathrm{y}^{-1}\right)$ & $\operatorname{Incr}\left(\mathrm{cm}^{\left.-y^{-1}\right)}\right.$ \\
\hline Fallow ma. (Co) & $46 \pm 4.3 b$ & $3556 \pm 315 b$ & $1575 \pm 162 b$ & $1.51 \pm 1.57 b$ \\
\hline Forêt dév. & $58 \pm 5.9 \mathrm{a}$ & $4412 \pm 397 a$ & $2108 \pm 209 a$ & $2.13 \pm 1.47 \mathrm{a}$ \\
\hline Forest l.v. & $63 \pm 8.1 \mathrm{a}$ & $4812 \pm 350 \mathrm{a}$ & $2279 \pm 160 \mathrm{a}$ & $2.06 \pm 1.22 \mathrm{a}$ \\
\hline Forest man. & $61 \pm 5.2 \mathrm{a}$ & $4683 \pm 390 a$ & $2022 \pm 150 a$ & $2.36 \pm 1.26 \mathrm{a}$ \\
\hline Fallow l.v. & $60 \pm 5.5 \mathrm{a}$ & $4593 \pm 400 a$ & $2280 \pm 194 \mathrm{a}$ & $2.02 \pm 1.19 \mathrm{a}$ \\
\hline Forest and. & $58 \pm 4.7 \mathrm{a}$ & $4375 \pm 368 \mathrm{a}$ & $2053 \pm 198 \mathrm{a}$ & $2.26 \pm 1.42 \mathrm{a}$ \\
\hline Average & $57.67 \pm 5.6$ & $4405 \pm 370$ & $2053 \pm 179$ & $2.05 \pm 1.36$ \\
\hline
\end{tabular}

In the same column, the averages followed by the same letter are not significantly different (Newmann-Keuls test at 5\%). $\left(\right.$ g.t $\left.\mathrm{t}^{-1} \cdot \mathrm{t}^{-1}\right)$ : gram per tree and per tapping; $\left(\mathrm{g} \cdot \mathrm{t}^{-1} \cdot \mathrm{y}-1\right)$ : gram per tree and per year; $\left(\mathrm{kg} \cdot \mathrm{ha}^{-1} \cdot \mathrm{y}^{-1}\right)$ : Kilogram per hectare per year; $\left(\mathrm{cm} \cdot \mathrm{an}^{-1}\right)$ : centimeter per year Yield: Rubber yield; Incr: Annual average increment $\left(\mathrm{cm}\right.$. year $\left.^{-1}\right)$

\section{Physiological Parameters of Trees}

The results of the physiological profile of the first and ninth years of experimental tapping on the moderate-metabolism clone GT 1, have been recorded in Tables 4 and 5. Overall, the physiological profile was good (wellbalanced) from tree tapping start to the end of experiment. It was not influenced by land preparation method. The average rate of dry rubber content of the latex was good $(44.88 \pm 1.5 \%)$ at tree tapping start, had a slight improvement at the end of experiment $(46.12 \pm 1.88 \%)$. The average sucrose and inorganic phosphorus content of the latex at tree tapping start was good $\left(12.25 \pm 2.11 ; 17.35 \pm 1.87 \mathrm{mmol}^{-1} \mathrm{l}^{-1}\right)$ also had a slight improvement at the end 
of experiment $\left(12.52 \pm 2.67 ; 20.44 \pm 2.37 \mathrm{mmol}^{-1} \mathrm{l}^{-1}\right.$. The average thiols group contents of the latex, at rubber tree tapping start, was good $(0.75 \pm 0.19$ mmol..$^{-1}$ ), had a relative and no-consequence regression at the end of experiment.

Table 4: Physiological profile of clone GT 1 trees subjected to different preceding crops and land preparation methods after a year of tapping

\begin{tabular}{|c|c|c|c|c|}
\hline Treatments & DRC (\%) & Suc $\left(\mathrm{mmol} . \mathrm{I}^{-1}\right)$ & Pi $\left(\mathbf{m m o l . l ^ { - 1 } )}\right.$ & R-sh (mmol. $\left.\mathrm{l}^{-1}\right)$ \\
\hline Fallow ma. (Co) & $46.76 \pm 1.98 \mathrm{a}$ & $14.02 \pm 2.63 \mathrm{a}$ & $21.87 \pm 2.29 a$ & $0.65 \pm 0.18 a$ \\
\hline Forest dév. & $45.78 \pm 2.63 \mathrm{a}$ & $11.87 \pm 2.51 \mathrm{a}$ & $19.45 \pm 2.06 \mathrm{a}$ & $0.72 \pm 0.26 \mathrm{a}$ \\
\hline Forest l.v. & $46.08 \pm 1.16 \mathrm{a}$ & $12.18 \pm 2.35 \mathrm{a}$ & $19.70 \pm 3.33 \mathrm{a}$ & $0.72 \pm 0.22 \mathrm{a}$ \\
\hline Forest man. & $46.16 \pm 1.55 \mathrm{a}$ & $12.21 \pm 3.00 \mathrm{a}$ & $21.70 \pm 2.04 \mathrm{a}$ & $0.73 \pm 0.28 \mathrm{a}$ \\
\hline $\begin{array}{l}\text { Fallow 1.v. } \\
\text { Forest and. }\end{array}$ & $\begin{array}{l}46.48 \pm 1.60 \mathrm{a} \\
45.43 \pm 2.41 \mathrm{a}\end{array}$ & $\begin{array}{l}13.36 \pm 2.56 \mathrm{a} \\
11.46 \pm 2.99 \mathrm{a}\end{array}$ & $\begin{array}{l}21.83 \pm 2.58 \mathrm{a} \\
18.10 \pm 1.92 \mathrm{a}\end{array}$ & $\begin{array}{l}0.73 \pm 0.25 \mathrm{a} \\
0.74 \pm 0.17 \mathrm{a}\end{array}$ \\
\hline Average & $46.12 \pm 1.88$ & $12,52 \pm 2,67$ & $20.44 \pm 2.37$ & $0.72 \pm 0.23$ \\
\hline
\end{tabular}

In the same column, the averages followed by the same letter are not significantly different

(Newmann-Keuls test at 5\%). Ex.S (\%): average dry rubber content rate of the latex expressed as a pourcentage: Sac $\left(\mathrm{mmol} . \mathrm{I}^{-1}\right)$ :average sucrose content of the latex expressed in

millimoles per liter; $\mathrm{Pi}\left(\mathrm{mmol} .^{-1}\right)$ :average inorganic phosphorus content of the latex expressed in millimoles per liter; $\mathrm{R}$-sh $\left(\mathrm{mmol} . \mathrm{l}^{-1}\right)$ : average thiol group contents of latex expressed in millimole per liter.

Table 5: Physiological profile of clone GT 1 trees subjected to different preceding crops and land preparation methods after nine years of experiment

\begin{tabular}{ccccc}
\hline Treatments & DRC $(\boldsymbol{\%})$ & Suc $\left(\mathbf{m m o l .}^{-\mathbf{1}}\right)$ & Pi $\left(\mathbf{m m o l .} \mathbf{l}^{\mathbf{1}}\right)$ & R-sh $\left(\mathbf{m m o l . ~}^{\mathbf{1}}\right)$ \\
\hline Fallow ma. $(\mathbf{C o})$ & $\mathbf{4 5 . 7} \pm \mathbf{1 . 3 3} \mathbf{~ a}$ & $\mathbf{1 2 . 6} \pm \mathbf{1 . 6 3} \mathbf{a}$ & $\mathbf{1 7 . 9} \pm \mathbf{2 , 0 9} \mathbf{a}$ & $\mathbf{0 . 7 0} \pm \mathbf{0 . 0 8} \mathbf{a}$ \\
Forest dév. & $44.7 \pm 2.41 \mathrm{a}$ & $12.7 \pm 2.31 \mathrm{a}$ & $15.2 \pm 1.46 \mathrm{a}$ & $0.76 \pm 0.26 \mathrm{a}$ \\
Forest 1.v. & $44.6 \pm 1.06 \mathrm{a}$ & $9.8 \pm 2.25 \mathrm{a}$ & $17,3 \pm 2.33 \mathrm{a}$ & $0.74 \pm 0.22 \mathrm{a}$ \\
Forest man. & $46.1 \pm 1.35 \mathrm{a}$ & $12.3 \pm 2.00 \mathrm{a}$ & $16.1 \pm 1.44 \mathrm{a}$ & $0.73 \pm 0.18 \mathrm{a}$ \\
Fallow l.v. & $46.4 \pm 1.30 \mathrm{a}$ & $13.7 \pm 2.16 \mathrm{a}$ & $16.8 \pm 2.38 \mathrm{a}$ & $0.70 \pm 0.23 \mathrm{a}$ \\
Forest and. & $42.3 \pm 2.11 \mathrm{a}$ & $12.4 \pm 2.29 \mathrm{a}$ & $20.8 \pm 1.52 \mathrm{a}$ & $0.84 \pm 0.17 \mathrm{a}$ \\
\hline Average & $\mathbf{4 4 . 8 8} \pm \mathbf{1 . 5 9}$ & $\mathbf{1 2 . 2 5} \pm \mathbf{2 . 1 1}$ & $\mathbf{1 7 . 3 5} \pm \mathbf{1 . 8 7}$ & $\mathbf{0 . 7 5} \pm \mathbf{0 . 1 9}$ \\
\hline
\end{tabular}

In the same column, the averages followed by the same letter are not significantly different

(Newmann-Keuls test at 5\%).Ex.S (\%): average dry rubber content rate of the latex

expressed as a pourcentage: Sac $\left(\mathrm{mmol} . \mathrm{l}^{-1}\right)$ :average sucrose content of the latex expressed in

millimoles per liter; $\mathrm{Pi}\left(\mathrm{mmol} . \mathrm{l}^{-1}\right)$ :average inorganic phosphorus content of the latex

expressed in millimoles per liter; R-sh $\left(\mathrm{mmol}^{-1} \mathrm{l}^{-1}\right)$ : average thiol group contents of latex expressed in millimole per liter. 
Table 6: References values of the most important physiological parameters of the latex (Jacob et al., 1987)

\begin{tabular}{|c|c|c|c|c|}
\hline & DRC (\%) & Suc $\left(\mathrm{mmol.l^{-1 }}\right)$ & $\mathrm{Pi}\left(\mathrm{mmol.l^{-1 }}\right)$ & R-SH (mmol. $\left.\mathrm{l}^{-1}\right)$ \\
\hline Very high & $>43$ & $>12$ & $>25$ & $>0.90$ \\
\hline High & 38 to 43 & 9 to 12 & 20 to 25 & 0.80 to 0.90 \\
\hline Medium & 33 to 38 & 6 to 9 & 15 to 20 & 0.60 to 0.80 \\
\hline Low & 29 to 33 & 4 to 6 & 10 to 15 & 0.50 to 0.60 \\
\hline Very low & $\leq 29$ & $\leq 4$ & $\leq 10$ & $\leq 0.50$ \\
\hline
\end{tabular}

\section{Tapping Panel Dryness}

The average rate of diseased panel length, all land preparation methods depending on the preceding crop combined, was low $(3.59 \pm 1.74 \%)$ after nine years of experiment (Table 7). These rates were lower and considered acceptable because less than 5\%, regardless of the experiment plot.

The different preceding crops and plot preparation methods were significantly equivalent with respect to the rates of diseased panel length of clone GT 1.

\section{Tree Mortality due to Root Disease (Fomes)}

The different preceding crops and plot preparation methods had a significant influence on the average rate of clone GT 1 trees infected by root rot, which is the root disease due to the attack of soil fungi, including the genus Fomes $(8.33 \pm 0.42 \%)$ after nine years of experiment (Table 7).Indeed, three groups were distinguished. Group 1 consisted of "Fallow ma; Forest dev and Fallow l.v" treatments whose respective diseased tree rates were statistically comparable $(5 \pm 0.52 \%, 5 \pm 0.69 \%$ and $02 \pm 0.13 \%)$ and significantly lower than those of the other treatments. Then, "Forest and; $8 \pm 0.23 \%$ and Forest lv; $11 \pm 0.10 \%$ "treatments of same significance which made up group 2 .

Finally, Group 3 "forest man" plot had a diseased tree rate of $19 \pm 0.80$ $\%$, statistically higher than all other preceding crops and land preparation methods, including the control (Table 7).

Table 7: Percentages of dry trees (TPD $(\%)$ and tree mortality due to root disease (Fomes)

of clone GT 1, subjected to different preceding crops and land preparation methods after nine years of experiment

\begin{tabular}{ccc}
\hline Treatments & loss $(\boldsymbol{\%})$ & LEM(\%) \\
\hline Fallow ma. $(\mathbf{C o})$ & $\mathbf{5} \pm \mathbf{0 . 5 2} \mathrm{c}$ & $\mathbf{4 . 1 7} \pm \mathbf{1 . 9 3} \mathbf{a}$ \\
Forest dév. & $5 \pm 0.69 \mathrm{c}$ & $3.32 \pm 1.14 \mathrm{a}$ \\
Forest l.v. & $11 \pm 0.10 \mathrm{~b}$ & $2.69 \pm 1.01 \mathrm{a}$ \\
Forest man. & $19 \pm 0.80 \mathrm{a}$ & $4.17 \pm 1.93 \mathrm{a}$ \\
Fallow l.v. & $02 \pm 0.13 \mathrm{c}$ & $3.04 \pm 2.29 \mathrm{a}$ \\
Forest and. & $08 \pm 0.27 \mathrm{~b}$ & $4.2 \pm 2.14 \mathrm{a}$ \\
\hline Average & $\mathbf{8 . 3 3} \pm \mathbf{0 . 4 2}$ & $\mathbf{3 . 6 0} \pm \mathbf{1 . 7 4}$ \\
\hline
\end{tabular}

In the same column, the averages followed by the same letter are not significantly different (Newmann-Keuls test at 5\%). LEM: diseased panel length 


\section{Impact of different land preparation methods depending on the preceding crop on the economic profitability of clone GT 1}

Table 8 shows land preparation costs, revenues and profit margins.

The economic profitability of the different preceding crops and plot preparation methods, in relation to fresh rubber yield data, was assessed according to operating expenses and revenues of clone GT1 (Table 8).

The plot preparation costs of clone GT 1, showed that the plot which had mechanically prepared forest "Forest 1.v" as preceding crop gave the highest amount (835000 CFAF) against 635000 CFAF for "Forest and" treatment. In the case of other treatments, "Forest man, Forest dev, Fallow 1v and Fallow ma", the preparation costs were respectively 263000; 295000; 360500 and $163000 \mathrm{CFAF}$. The most significant gain (813641 CFAF.ha ${ }^{-}$ ${ }^{1}$. year $^{-1}$ ) was recorded in the plots of "Fallow lv" treatment. It was, indeed, statically higher than those of the other plots. The "forest dev" treatment plots generated a profit (790011 CFAF.ha ${ }^{-1} \cdot$ year $^{-1}$ ) statistically identical to that of the "forest man" plot (778734 CFAF.ha ${ }^{-1} \cdot$ year $^{-1}$ ), and higher than that of "fallow ma; forest lv; forest and" treatments which were less profitable with respective amounts of $\left(648440 ; 339156 ; 422206\right.$ CFAF.ha $^{-1}$.year $\left.^{-1}\right)$.

The "fallow 1.v" treatment yielded a profit margin statistically higher than that of "Forest $1 . \mathrm{v}$ " treatment whose profit margin was lower than that of the "Forest and" treatment. The preceding crop, fallow, mechanically cut down, followed by the opening of rows with a $\mathrm{V}$-shaped shovel was, basing on economic profitability, the best option for land preparation for the establishment of rubber tree plantation. This classification resulting from the economic profitability recorded was in favor of the plot which had Fallow as preceding crop since it was prepared mechanically (Jachère 1.v).

Table 8: Profit margins (CFAF.ha ${ }^{-1}$.year ${ }^{-1}$ ) depending on different preceding crops and land preparation methods applied to clones GT 1

\begin{tabular}{cccc} 
& \multicolumn{3}{c}{ Profil margins (CFAF.ha $^{-\mathbf{1}}$.year ${ }^{-\mathbf{1}}$ ) } \\
\cline { 2 - 4 } Treatments & Preparation costs & revenues & Profit margins \\
\hline Fallow ma $($ Co). & $\mathbf{1 6 3 0 0 0}$ & $\mathbf{8 1 1 4 4 0}$ & $\mathbf{6 4 8 4 4 0} \pm \mathbf{5 4 2 3} \mathbf{~ b}$ \\
Forest dév. & 295000 & 1085011 & $790011 \pm 3044 \mathrm{ab}$ \\
Forest l.v. & 835000 & 1174656 & $339156 \pm 3883 \mathrm{~d}$ \\
Forest man. & 263000 & 1041734 & $778734 \pm 4916 \mathrm{ab}$ \\
Fallow l.v. & 360500 & 1174141 & $813641 \pm 5646 \mathrm{a}$ \\
Forest and. & 635000 & 1057706 & $422206 \pm 2200 \mathrm{c}$ \\
\hline Average & $\mathbf{2 5 5 1 5 0 0}$ & $\mathbf{1 0 5 7 4 4 8}$ & $\mathbf{6 3 2 ~ 0 3 2} \pm \mathbf{4 1 8 5}$ \\
\hline
\end{tabular}

In the same column, the averages followed by the same letter are not significantly different (Newmann-Keuls test at 5\%).F.CFA.ha ${ }^{-1} \mathrm{an}^{-1}$ : CFA franc per hectare and per year. 


\section{Discussion \\ Effect of Preceding Crops on the Evolution of Hevea brasiliensis Clone GT 1}

The assessment of the incidence of root rot, a dreadful root disease caused by the genus Fomes on Hevea brasiliensis clone GT 1, indicated a relatively high rate of loss, for plots having forest as preceding crop and particularly regarding the forest, with manual preparation as a cropping technique $(19 \pm 0.80 \%)$. This result confirms the hypothesis of a positive correlation between forest as preceding crop and the proliferation of Fomes foci. It therefore seems obvious that the preceding crop, particularly Forest, is of particular importance in the proliferation of root rot caused by the genus Fomes, as mentioned by several authors (Delabarre and Serier (1995), Thierry (2005) and Wahounou. et al., 2017. They showed that this fungus, pathogen responsible for root disease is abundant in forest soils, and can therefore sensibly influence the percentage of living trees in a plantation. The proximity of the Fomes fungus with preceding crop Forest or forest itself comes from the fact that it is a wood-eating fungus, which thrives well in an environment where there are woody essences or species. It multiplies abundantly and quickly in the forest and especially when the forest is cut down because of the abundance of its food. This reason also explains its near absence or limited presence on preceding savanna or fallow land which has almost no woody essence and therefore nothing to feed on and multiply. These lands have a low or even very low rate of inoculum of the genus Fomes. This also explains the fact that the selection of land with a preceding crop free of woody species (fallow) is overall the most effective method of preventive control. Our results show that preceding crop Fallow, free of residual strains as well as a part of the roots which greatly reduces the amount of inoculum, has recorded a lower rate of trees with root rot, which was in the order of $2 \%$. They thus confirm those of the works of Adiko and Gnonhouri, 1997; Floret and Pontanier, 2001, which showed that plots having fallow as preceding crop are indeed a means of reducing the rate of soil infestation of by plant pests.

Despite the high rate of Fomes observed in some plots of our study, it should be noted that the losses due to this fungal parasite do not affect for the moment the overall yield of these plots.

\section{Effect of Different Land Preparation Methods on the Evolution of Hevea brasilliensis Clone GT 1}

Preceding crops forest or fallow, mechanically prepared, have agronomic performances that are more interesting or important than those recorded on manually-prepared preceding crops. In fact, the lowest growth $\left(1.51 \mathrm{~cm}\right.$ year $\left.^{-1}\right)$ was observed in the plot which had the lowest yield (1575 $\mathrm{kg} \cdot \mathrm{ha}^{-1} \cdot \mathrm{year}^{-1}$ ), namely the one that had manually-prepared fallow as preceding 
crop. These results show the importance of land mechanical preparation when the soil characteristics require it. They thus confirm those of Le Roux (1994); Anonymous 1, 2013 works. The latter showed that the soil of southwestern Côte d'Ivoire consists mainly of gravelly and lateritic layers located at 60 to $80 \mathrm{~cm}$ deep, which is a limiting factor to rubber tree rooting. They also proved that for the plots which had fallow or mechanically-prepared forest as preceding crop, the taproot grows up to 1 meter deep, lower limit of the soil horizon reached when land preparation is done mechanically. Thus, the taproots develop specifically in areas where the compactness of the soil has been reduced by the mechanical preparation of the land. Such depths were not reached in plots which had fallow or manually-prepared forest as preceding crop. The development of the taproot was therefore difficult. Orthotropic growth was up to $60 \mathrm{~cm}$ deep (Boyer, 1982; Le roux 1994). At this level, the compacted layer completely blocked down ward growth. There were thus unsuccessful "attempts" of plagiotropic development. Such a development leads to a bad anchoring of the tree and difficulties of hydromineral feeding. The lateritic layer is a major obstacle to the development of the taproot. This very low permeability layer retains water, which can cause root asphyxiation. On the other hand, the coarse elements of the profile had a more or less unfavorable effect on soil fertility. Finally, their water retention capacity varied from 10 to $36 \%$ depending on whether there were alterites or concretions (Boa, 1989). According to their thickness, their density and their position, the growth of rubber trees can be reduced by 20 to $30 \%$ (Compagnon, 1986; Anonymous 2, 2008).

\section{Economic Analysis of Different Preceding Crops and Land Preparation Methods on Clone GT 1}

The economic analysis (expenses and revenues) made from practical data was decisive in order to select the best land preparation method, since the basis of the economic calculation comes from field agronomic data. Overall, and with some variations, the economic results were in the same direction as the agronomic data. Thus, the economic result points out mechanicallyprepared fallow as the best option of preceding crop and land technical preparation.

This choice is very important for the national rubber-growing industry. Indeed, this choice is in line with the position of the people in charge of this industry who have advocated for at least 5 years the extension of rubbergrowing areas to the savannah and/or fallows. The sector actively and indirectly participates in the fight against deforestation and also contributes to the constitution of secondary forest. Rubber-growing plant cover actually has the characteristics of secondary forest (Gilot et al., 1993, Obouayeba et al., 2015). 


\section{Conclusion}

This study was carried out in order to compare, agronomically and economically, different methods of land preparation depending on the preceding crop (adapted to industrial and village plantations) and to study their influence on the evolution of planted plots (root diseases, growth, yield etc.). The results showed that the rate of rubber trees found in the plots was good and had varied with the land preparation method depending on the preceding crop. Vegetative growth at tapping, the average rubber yield and the rate of tree loss due to the genus Fomes were influenced by land preparation method. Despite the good productivity, the physiological condition of rubber trees was good, characterized by a well-balanced physiological profile and a low tapping panel dryness rate, independently of treatments. The Agroeconomic results showed that mechanically-prepared fallow was the best preceding crop and land preparation method. This technical option is a real commitment of the rubber-growing industry to the national policy of fighting against deforestation and an important contribution to the formation of secondary forest thanks to the characteristics of secondary forest showed by the rubbergrowing plant cover.

\section{References:}

1. Adiko (A) \& (PC.) Gnonhouri. (1997). Influence of perennial legume fallows on nemato fauna in west-central Côte d'Ivoire. In: Proceedings of the Workshop - Fallow and maintenance of fertility (Bamako 2-4 October 1997) - Project 7 ACP RPR 269. Improvement and management of fallow land in West Africa. $146 \mathrm{p}$.

2. Anonymous 1, (2013). Establishment and maintenance of immature rubber crops in Côte d'Ivoire. FIRCA / APROMAC-Guide for the Agricultural Advisor Volume 2, internal document, $56 \mathrm{p}$.

3. Anonymous 2, (2008). Rubber Planter Manual. FIRCA / APROMAC, internal document, $48 \mathrm{p}$.

4. Ashwell G., (1957). Colorimetric analysis of sugar. Meth. Enzymol., 3: 73-105.

5. Boa, D. (1989): Characterization, hydrodynamic properties, constraints and potentialities of gravelly soils: case of Booro-Borotou (Touba region, North-West of Côte d'Ivoire). Thesis of DoctorAgronomist Engineer, University of Abidjan, 135p.

6. Brou Y. T., Akindes F., \& Bigot S., (2005). Climate variability in Côte d'Ivoire: between social perceptions and agricultural responses, Cahiers Agricultures vol. 14, No. 6, November-December 2005, pp. 533-540

7. Boyne A. F. \& Ellman G. L., (1972). A methodology for analysis of tissue sulphydryl components. Anal. Biochem., 46: 639-653. 
8. Boyer, J (1982): Ferralitic soils. Fertility factors and land use. Volume $\mathrm{X}$ Initiations-Technical Documentations No. 52, ORSTOM, Paris: 237-244.

9. Compagnon, P (1986): Natural rubber. Biology-Culture-Production Ed. G.-P. Maisonneuve \& Larose: 119-153.

10. Chapuset T., Gnagne M., Legnate H., Koffi E \& Clement-Demange A., (2000). Fields of Large Scale clones in Côte d'Ivoire, situation in 1999. Sea Report No. 01/2000-A March 2000, 40-63.

11. Delabarre, M. \& Serier, J. B. (1995). Rubber trees. Technician of Tropical Agriculture (FRA), Paris (FRA): Maisonneuve and Larose, 238p.

12. Delabarre, M. \& Eschbach, J. M. (2002). Special agriculture. Plants for other uses: rubber plants, in Mémento de l'agrronome. Montpellier, CIRAD pp 1185-1197.

13. Floret Ch \& Pontanier R. (EDS), (2001). Summer fallow in tropical Africa. From natural fallow to improved fallow. The point of knowledge. Paris, John Libbey Eurotext, 356p.

14. Gilot, C., Lavelle, Keli, J., Kouassi, P. \& Guillaume, G. (1993). Biological activity of soil under rubber plantations in Côte d'Ivoire. Rapport DEA, IDEFOR-DPL n ${ }^{\circ}$ 37/93- $\mathrm{T}$.

15. Gohet, E., Prévôt, J.-C., Eschbach, J.-M., Clément, A., \& Jacob, J.-L., (1996). Hevea latex production, relationship with tree growth, influence of clonal origin and Ethrel stimulation. In: IRRDB (Editor), Symposium on physiological and molecular aspects of the breeding of Hevea brasiliensis, Brickendonbury, pp. 200-216.

16. Jacob J.L., Serres E., Prevot J.C., Lacrotte R., Clement- Vidal A., Eschbach J.M. \& D'auzac J. (1988). Development of the latex diagnosis. Agritop, 12: 97-118.

17. Jacob, J.L. Prevot, J.C. Lacrotte \& R. Eschbach, J.M. (1995). Le diagnostic latex. Plantations, recherché, développement, 2 (1), 34-37.

18. Jacob, J.L. Prevot, J.C. Lacrotte, R. Gohet, E. Clement, A. Gallois, R. Joet, T., Pujade-Renaud, V. \& D'auzac, J. (1998). The biological mechanisms of rubber production by Hevea brasiliensis. Communication from the IRRDB 1997 Worshop, Ho Chi Minh City, Vietnam, 14-15 October 1997, 13.

19. Keli, J. Z., Obouayeba, S \& Zehi, B (1992). Influence of some food systems on the behavior of young rubber trees in the lower Ivory Coast. Agricultural Systems in Africa, 2 (1): 41 - 48.

20. Kouassi A., M., Kouame K., F., Goula B. T. A., Lasm T., Paturel J., \& E., Biemi J., (2008). Influence of climate variability and land-use change on the rainfall-discharge relationship from a global modeling 
of the N'zi (Bandama) watershed in Côte d'Ivoire. Rev., Ivoir., Sci., Technol., 11 (2008) 207-229.

21. Le Roux, Y. (1994): Establishment of the root architecture of Hevea brasiliensis. Comparative study of sowing and microbouture. Thesis University of Aix Marseille III. Saint-Jerome Faculty of Science and Technology; pp 35-40. 295p.

22. Mahyao A., Soumahin E.F., Koffi C., Coulibaly L.F., N'guessan A.E.B., Kouame C. \& Obouayeba S., (2014). Economic Analysis of Compensating Systems for the Scarcity of Tapping Labour in the Rubber Industry in Côte d'Ivoire. Journal of Rubber. Research, 17(1), 34-44.

23. Monnier Y., (1983). Vegetation. In:atlases of young Africa Ivory Coast. J. A, pp. 16-18.

24. Obouayeba S., (2005). Contribution to the determination of the physiological maturity of the bark for the tapping of Hevea brasiliensis Muell. Arg. (Euphorbiaceae): Opening standard. Thesis University of Cocody, UFR Biosciences, Ivory Coast, 225p.

25. Obouayeba S., Dian K., Boko A.M.C, Gnagne Y.M, \& Ake S., (2005). Effect of planting density on growth and yield productivity of Hevea brasiliensis Muell. Arg. Clone 235. J Rubb. Res., 8(4), 257- 270.

26. Obouayeba S., Boad D., Dian K., Ouattara N.\& Keli Z.J.,(2000). Dynamics of vegetative growth and productivity of hevea: brasiliensis. In determing tapping nprms. J. Rub. Res., 3 (1): $53-62$.

27. Obouayeba S. Boa D \& Keli Z.J., (1996). Adequacy between quantity of stimulating pulp and rubber production of Hevea brasiliensis in south-eastern Côte d'Ivoire. Tropicultura, 14 (2), 54-58.

28. Obouayeba S, Boko M. C. A, Soumahin E. F.,. Elabo A. A. E, Dea G. B, Badou E. A, Christophe Kouamé, Zéhi B.\& Kéli Z. J. (2015). Natural rubber-based intercropping systems in côte d'ivoire:a review of forty years of work. Rubber Science, 28 (3): 211-226, 2015.

29. Pathiratna, L. S. S., Seneviratna, P., Perera, M.K.P. \& Balasooriya, C.K. (2006). Bark cracking disorder in the lower trunk region of seedling and in the root stock of bud grafted trees of Hevea brasiliensis Muell.Arg. Ceylon Journal of Science (Bio Sci) 35, 79-86.

30. Pathiratna, L.S.S. \& Perera, M.K.P. (2003). Contour and East - West row planting systems of rubber (Hevea) for intercropping: Part II. Distribution of fine roots in the inter row space. Journal of the Rubber Research Institute of Sri Lanka 86, 1-10.

31. Prevot J.C., Jacob J.N.L., Lacrotte R., Vidal A., Serres E., Eschbach J. M \& Gigault J., (1986). Physiologocal parameters of latex from Hevea brasiliensis. Their use in the study of the laticiferous system. Typology of functioning production mechanisms. Effects of stimulation. In : 
IRRDB physiology and recolte de latex meeting, Haiman, 1986. Pan Yanquing and Lhao Canwen. Eds, South China Academy of Tropical Crops of functioning (Hainan), pp 136-157.

32. Seneviratne \& Privani, (2005). Production of planting material for rubber replanting and new planting programmes in Sri Lanka. Bulletin of the Rubber Research Institute of Sri Lanka 46, 17-24.

33. Thierry Michels, (2005). Adapting the management of rubber plantations to the diversity of village farms (case study in Cameroon): Thesis, Institut National Agronomique Paris-Grignon, France, 302 p.

34. Taussky H.H. \& Shorr E., (1953). A micro colorimetric method for the determination o fin organic phosphorus. J. Biol. Chem., 202: $675-$ 685 .

35. Wahounou P.J., Coulibaly B.,Gnonhouri G.P. \& Adiko A. (2017): Teak (Tectonagrandis) decay associated with Verticillium sp. And Fomes sp. Within reforestation areas in Côte d'Ivoire. Journal of Tropical Forest Science 29(3): 363-370 (2017) 